\title{
PEARL MILLET GROWTH ON AN EROSION-AFFEGTED SOIL IN THE SAHEL
}

\author{
By KARLHEINZ MICHELS $\dagger$ and CHARLES L. BIELDERS $\ddagger$ \\ International Crops Research Institute of the Semiarid Tropics (ICRISAT) Sahelian Center, \\ Niamey, Niger
}

(Accepted 7 April 2005)

\begin{abstract}
SUMMARY
The residual effects of three years' mulch application and the associated erosion processes, such as soil loss or deposition, on pearl millet (Pennisetum glaucum) growth have been investigated on a Sahelian sandy soil in field and pot studies. The smallest millet yields were found on unmulched eroded plots despite mineral phosphorus $(\mathrm{P})$ applications, whereas stover mulching or manure and urine consistently resulted in larger yields. Bioassays revealed that aluminium $(\mathrm{Al})$ by itself was not growth-limiting. Neither nematodes nor lack of micronutrients contributed to the small millet yields. On soil from eroded plots, millet dry matter yield tripled after $\mathrm{P}$ addition, and increased by a factor of 13.5 when additional nitrogen $(\mathrm{N})$ was applied. High $\mathrm{P}$ availability was found to be the key to reversing decline in yields on erosion-affected fields, but the addition of organic material is a prerequisite to prevent acidification. Manure was more effective than straw because of the large amounts of $\mathrm{N}$ and $\mathrm{P}$ it contained. The addition of small quantities of lime $\left(\mathrm{CaCO}_{3}\right)$ may partly compensate for organic matter addition by increasing soil $\mathrm{pH}$ and reducing $\mathrm{P}$ fixation. $\mathrm{P}-\mathrm{Bray}$ was not a suitable indicator of plant available $\mathrm{P}$ on degraded sandy acid soils.
\end{abstract}

\section{INTRODUGTION}

The removal of topsoil from arable land by wind or water erosion leads to modified soil physical, chemical and biological conditions for crop cultivation (Lal et al., 1989). It usually results in a loss of the soil's productive capacity at sites where erosion occurs. On areas of deposition, the sediment may either increase or decrease soil fertility depending on the quantity of the deposited material and its chemical and physical properties. Erosion processes have a significant impact on land productivity in the West African Sahel, a semi-arid region where both wind and water act as erosive forces (Michels et al., 1995). This is also true for the sandy aeolian soils of western Niger, although water erosion is of lesser importance than wind erosion on cultivated land in this area (Bielders et al., 2001). Furthermore, nutrient mining by continuous cropping without return of the nutrients in harvested crops constitutes another dominant process in the overall decline in land quality in the Sahel (Subbarao et al., 2000). On the sandy, weakly buffered soils of western Niger, the consequences of these degradation processes are fairly well documented. It results in rapid acidification of the soil profile,

\footnotetext{
† Present address: Trautäckerstr. 25, 70593 Stuttgart, Germany.

$\ddagger$ Corresponding author: Present address: Dept. of Environmental Sciences and Land Use Planning,The Faculty of Bio-engineering, Agronomy and Environment, Université Catholique de Louvain, Croix du Sud 2, boite 2, B-1348 Louvain-la-Neuve, Belgium; Email address: bielders@geru.ucl.ac.be.
} 
replacement of essential nutrients such as $\mathrm{Ca}, \mathrm{Mg}$ and $\mathrm{K}$ by exchangeable $\mathrm{Al}$ and $\mathrm{H}$, the presence of exchangeable $\mathrm{Al}$ at levels potentially toxic to crops, $\mathrm{P}$-fixation due to low $\mathrm{pH}$ and high $\mathrm{Al}$ contents in the soil, loss of organic carbon $(\mathrm{OC})$, decreased levels of plant available $\mathrm{P}$, reduced biological activity, soil physical degradation and direct seedling damage by the soil erosion processes (e.g. Bielders et al., 2002; Buerkert and Lamers, 1999). Compared to the wet tropics, a reduction in the depth of the rooting zone is not a relevant problem in the deep sandy soils.

Although both wind and water erosion can be selective processes with respect to particle size, when losses in soil depth in excess of several $\mathrm{mm}$ per year are involved, this selectivity becomes secondary in relation to the total mass of soil lost. In this case, the changes induced by soil erosion encompass both the loss of a layer of bulk soil material (reduced depth of topsoil), and the accompanying loss of nutrients and organic matter in amounts equal to the product of the total mass of eroded material and the average nutrient content of the topsoil. In the sandy soils of western Niger, the weatherable nutrient content is negligible (West et al., 1984) and the cation exchange capacity $(\mathrm{CEC})$ is almost exclusively attributable to the soil organic matter (SOM) fraction, given the very low $(<5 \%)$ content of essentially kaolinitic clay. As a result, the total mass of plant available nutrients reflects the SOM content in the profile, but since SOM is mainly concentrated in the topsoil, nutrient availability is strongly susceptible to soil losses by wind or water erosion.

The after effects of erosion can result in further decreases in the generally small yields, in particular of the main Sahelian staple crop, pearl millet (Pennisetum glaucum). Whereas control techniques for wind erosion have been tested on-station and on-farm (Bielders et al. 2000; Michels et al., 1998), strategies for regaining crop productivity on affected fields are not well developed. Phosphorus $(\mathrm{P})$ has been identified as the most limiting nutrient for millet production in the Sahel (Payne et al., 1992) and it has been shown that applying small doses of mineral $\mathrm{P}$ and nitrogen $(\mathrm{N})$ increased or even multiplied biomass production (Muehlig-Versen et al., 2003). Besides, drought stress cannot be effectively managed for millet production without first addressing soil $\mathrm{P}$ availability (Payne et al., 1992). Over time, yields commonly decline despite mineral fertilization, but this decline is dependent on the treatment: mulch/no mulch. The application of stover mulch counteracts yield decreases (Bielders et al., 2002) to some extent by enhancing soil P availability (Hafner et al., 1993; Rebafka et al., 1994) and reducing the amount of wind-blown soil (Bielders et al., 2000; Michels et al., 1995).

Experiencing a decline in yield after investments in expensive inputs and labour for erosion control is economically not viable and discourages resource-poor farmers from adopting this technology. The restoration of productivity on eroded land and the reversal of yield decline can only be managed successfully based on an understanding of the growth limiting factors. Due to possibly complex soil physical, chemical and biological interactions, the correct diagnosis of the unfavourable conditions for crop growth is a difficult but imperative task. When mechanisms for explaining yield differences on soils with different levels of degradation are better understood, these soils can be rehabilitated and large yields obtained using technologies appropriate for farmers. 
Our paper presents results from a series of field and pot experiments exploring strategies to reverse millet yield decline in the West African Sahel on a typical site exposed to different degrees of soil erosion or deposition. It builds upon a previous field study by Buerkert and Lamers (1999) addressing the extent of soil erosion in the Sahel and its impact on pearl millet yield. During a three-year field trial in southwest Niger, the authors had observed significant declines in the yield of millet over time despite annual additions of mineral $\mathrm{N}$ and $\mathrm{P}$ fertilizer, and irrespective of soil erosion or deposition, and irrespective of mulch applications. We conducted a series of follow-up field and pot trials to identify key factors for strategies to reverse this trend.

\section{MATERIALS AND METHODS}

Field trial: effects of crop residue, manure, fertilizer, and soil tillage on millet production and crop water use

This field trial took place in the growing seasons 1995 and 1996 on the site used by Buerkert and Lamers (1999) during the three previous cropping seasons at the International Crops Research Institute of the Semiarid Tropics (ICRISAT) Sahelian Center, in Sadoré, Niger (lat $13^{\circ} 15^{\prime} \mathrm{N}$, long $2^{\circ} 18^{\prime} \mathrm{E}$ ). The soil is classified in the U.S. Soil Taxonomy as a (sandy, siliceous, isohyperthermic) psammentic Paleustalf of the Labucheri soil series (West et al., 1984). There was a $1 \%$ slope from south to north. Buerkert and Lamers (1999) arranged the following three treatments in a randomized block design with three replicates comprising nine plots each $19 \mathrm{~m} \times 25 \mathrm{~m}$ : (i) an annual application of $2 \mathrm{tha}^{-1}$ of millet stover; (ii) a single application of polyethylene tubes of similar length and diameter as the millet stover and providing a similar degree of soil cover as the $2 \mathrm{tha}^{-1}$ millet stover; and (iii) an unmulched control. All the treatments had been fertilized annually with $30 \mathrm{~kg} \mathrm{Nha}^{-1}$ and $13 \mathrm{~kg} \mathrm{Pha}^{-1}$ as $165 \mathrm{~kg} \mathrm{ha}^{-1}$ single superphosphate. Over a 21 -month measurement period, the authors observed a cumulative erosion of almost $270 \mathrm{t} \mathrm{ha}^{-1}$ of soil from the unmulched control plots. In mulched plots between 160 and $200 \mathrm{t} \mathrm{ha}^{-1}$ of sediment was deposited. Because of the topographical position of the plots, soil loss may have resulted from both water and wind erosion whereas deposition resulted exclusively from sedimentation of windblown sediment.

In 1995, immediately before millet sowing, we introduced sub-plots with a soil tillage treatment: one half of each main plot was manually tilled to destroy the superficial soil crust using a hand-hoe on $0.5-\mathrm{m}$ wide strips $0.5 \mathrm{~m}$ apart. The other half remained untilled. Furthermore, within each of these sub-plots the following three treatments were applied to $80 \mathrm{~m}^{2}$ sub-sub-plots in May 1995: (i) $2 \mathrm{t} \mathrm{ha}^{-1}$ millet stover, (ii) no mulch, and (iii) $10 \mathrm{tha}^{-1}$ manure of small ruminants plus $1250 \mathrm{lha}^{-1}$ of urine. The continuation of treatments from the previous 1992-1994 trial (stover mulch/unmulched) allowed trends in soil properties and crop yields to be followed whereas the soil tillage and manure treatments simulated alternative strategies to regain productivity. The quantity of manure and urine was representative of fields 
where cattle or small ruminants have been kraaled overnight as practised by farmers in southwest Niger. Our own survey among farmers in the Niamey region had revealed that goats, sheep and cattle were kept in kraals overnight for between one and three weeks. In order to obtain $10 \mathrm{t}$ manure $\mathrm{ha}^{-1}$, an average of 2.5 nights is needed when one goat occupies $1 \mathrm{~m}^{2}$. The nutrient content of the dry manure applied was $1.8 \% \mathrm{~N}$, $0.4 \% \mathrm{P}, 2.1 \% \mathrm{~K}$ and $1.8 \% \mathrm{Ca}$.

Physical and chemical properties of soils in each plot were characterized in May 1995: the extent of the erosion crust area (Valentin and Bresson, 1992) was estimated from low-altitude aerial photographs, soil resistance using a hand-held penetrometer (Eijelkamp, The Netherlands), and soil water contents throughout the 1995 season using a Troxler neutron probe to calculate water balance (drainage, evapotranspiration [ET], and hence crop water use efficiency). Drainage was calculated according to the method of Klaij and Vachaud (1992). Chemical analyses were done for PBray-1 (Olsen and Sommers, 1982) and $\mathrm{pH}(2 \mathrm{M} \mathrm{KCl}$ and water). Concentrations of exchangeable $\mathrm{Ca}$ and $\mathrm{Mg}$ were measured by atomic adsorption, and $\mathrm{Na}$ and $\mathrm{K}$ by flame emission spectrophotometry, after extraction with $1 \mathrm{~N}$ ammonium acetate. Exchangeable $\mathrm{Al}$ and total acidity were determined according to McLean (1982).

On 20 June 1995 and on 3 June 1996 millet crops were sown manually in planting holes (so-called pockets) spaced $1 \times 1 \mathrm{~m}$ using the improved variety ICMV 89305. The experimental plots were weeded twice per year, and no mineral fertilizers were used in 1995. Because soil tillage had no effect at all, this treatment was replaced in 1996 by the application of fertilizer. Phosphorus at $20 \mathrm{~kg} \mathrm{P} \mathrm{ha}{ }^{-1}$ was then applied as single superphosphate immediately after sowing and incorporated slightly. Nitrogen at $45 \mathrm{~kg} \mathrm{ha}{ }^{-1}$ was applied as calcium ammonium nitrate and split into three equal doses: immediately after sowing, three weeks later and during shooting. Harvest took place in October each year.

Root length density was determined from soil samples taken on 8 September 1995 (flowering stage) at 11 depths directly under one millet pocket per plot. Roots were spread over a drawn grid with $20 \mathrm{~mm}$ line spacing and intersections of roots with the lines were counted. Root length was calculated as 'Intersection counts $\times$ Grid spacing $(\mathrm{cm}) \times(11 / 14)^{\prime}$. Root length density was then calculated by dividing the root length (cm) by the sample volume $\left(\mathrm{cm}^{3}\right)$.

\section{Pot trial I: Al toxicity effects on millet seedling emergence and growth}

A bioassay after Ahlrichs et al. (1991) was conducted at the ICRISAT station in Sadoré to test if aluminium toxicity was a contributing factor to the small millet yields reported by Buerkert and Lamers (1999). They had found significantly larger soil Al contents where millet yields were lowest - in the unmulched treatments which had the highest erosion rates. We took soil samples from nine field plots on 9 February 1996: three of the plots had received stover mulch during the last four millet growing seasons, three were unmulched, and three were taken from the previous plastic-mulch plot. Samples in the field were taken at three soil depths $(0-0.1,0.1-0.2$ and 0.4 $0.6 \mathrm{~m})$ and with three replicates from each plot, a total of 81 pots. The experimental 
layout was regarded as a blocked $3 \times 3$ factorial design, with nine replications consisting of the sub-sampling $\times$ field block combinations.

Samples of $0.5 \mathrm{~kg}$ soil were brought to $10 \%$ moisture content and placed into pots with $0.1 \mathrm{~m}$ diameter and $0.1 \mathrm{~m}$ height. Seeds of the millet variety 'ICMV 89305' were pre-germinated on filter paper in petri dishes at $25^{\circ} \mathrm{C}$ for $24 \mathrm{~h}$. Ten seeds with radicles 2-3 mm long were placed in each pot, covered with $90 \mathrm{~g}$ soil and kept in a shady place. After $72 \mathrm{~h}$ plants were separated from the soil, and root length and plant height were measured using a ruler. Only seedlings with final root lengths above $25 \mathrm{~mm}$ were used for the data analyses; these represented $84 \%$ of the total number of transplanted seeds. Plant data were analysed with Proc Mixed in SAS V. 6.12. Data were compared with those given by Ahlrichs et al. (1991) for Al toxicity effects. ANOVA error probabilities below 0.05 for treatment differences were regarded as significant.

\section{Pot trial II: Al toxicity effects on an improved versus a traditional millet variety}

The objective of this bioassay, also after Ahlrichs et al. (1991) and again conducted at the ICRISAT station in Sadoré, was to compare Al toxicity tolerance of the improved millet variety 'ICMV 89305' with the traditional variety 'Sadoré local'. Soil was taken from three bare (no amendments) field plots with the highest erosion rates, which had the largest $\mathrm{Al}$ contents according to Buerkert and Lamers (1999), at two depths (0.1-0.2 and 0.4-0.6 m respectively), using three separate samples per plot acting as replicates. In total, 18 pots were filled. The experimental layout was regarded as a blocked $3 \times 2$ factorial design, with three replicates consisting of the sub-sampling $\times$ field block combinations. Observations were made as described for pot trial I. Data were analysed with Proc GLM in SAS V. 6.12.

\section{Pot trial III: effects of $\mathcal{N}, P, K$, lime, micronutrients and a nematicide on millet growth}

The two field plots with the smallest millet yields in 1995 and the two plots with the largest yields were identified. Dry soil samples were taken on 30 March before the 1996 rainy season at $0-0.2 \mathrm{~m}$ depth and transferred in $9 \mathrm{~kg}$ portions into $647 \mathrm{l}$ pots of 'productive' and another 64 pots of rather 'unproductive' soil. This allowed for a randomized seven-factor experiment with $2^{7}=128$ combinations. Six treatments, each consisting of the zero and a high level were applied: (i) mineral $\mathrm{N}\left(\mathrm{NH}_{4} \mathrm{NO}_{3}\right.$ equivalent to $\left.45 \mathrm{~kg} \mathrm{Nha}^{-1}\right)$, (ii) mineral $\mathrm{P}\left(\mathrm{CaHPO}_{4}\right.$ equivalent to $\left.40 \mathrm{~kg} \mathrm{Pha}^{-1}\right)$, (iii) mineral $\mathrm{K}$ ( $\mathrm{KCl}$ equivalent to $100 \mathrm{~kg} \mathrm{~K} \mathrm{ha}^{-1}$ ), (iv) lime $\left(\mathrm{CaCO}_{3}\right.$ equivalent to $\left.250 \mathrm{~kg} \mathrm{ha}^{-1}\right)$, (v) the commercial micronutrients mixture Fetrilon Combi $\left(1 \mathrm{~kg} \mathrm{ha}^{-1}\right)$, and (vi) the nematicide Carbofuran $\left(4.4 \mathrm{~kg}\right.$ active ingredient ha $\left.{ }^{-1}\right)$. All rates were converted from $\mathrm{kg} \mathrm{ha}^{-1}$ to $\mathrm{g} \mathrm{kg}^{-1}$ soil assuming a topsoil thickness of $0.15 \mathrm{~m}$.

The soil in all the pots was wetted to $10 \%$ moisture and left to equilibrate for $24 \mathrm{~h}$ before sowing 10 pearl millets seeds (variety ICMV 89305) pre-treated with the fungicide Thioral $\left(2 \mathrm{~g} \mathrm{~kg}^{-1}\right.$ seed). Pots were randomly placed in an air-cooled greenhouse at the ICRISAT station in Sadoré and watered and rotated daily to compensate for possible irregular temperature patterns within the greenhouse. The 
Table 1. Soil physical and chemical properties in a millet field in May 1995 after three years of mulch application and erosion impact. ICRISAT, Sadoré, Niger.

\begin{tabular}{|c|c|c|c|c|c|c|c|c|}
\hline & \multirow[t]{2}{*}{$\begin{array}{c}\text { Erosion crust } \\
\text { (\% of soil } \\
\text { surface) }\end{array}$} & $\begin{array}{c}\text { Penetration } \\
\text { resistance } \\
\left(\mathrm{kN} \mathrm{m}^{-2}\right.\end{array}$ & $\begin{array}{r}\text { P-Bray } \\
\left(\mathrm{mg} \mathrm{kg}^{-1}\right.\end{array}$ & $\begin{array}{c}\mathrm{Al}^{3+} \\
\left(\mathrm{cmol} \mathrm{kg}^{-1}\right)\end{array}$ & $\begin{array}{c}\mathrm{K}^{+} \\
\left(\mathrm{cmol} \mathrm{kg}^{-1}\right)\end{array}$ & $\begin{array}{r}\text { P-Bray } \\
\left(\mathrm{mg} \mathrm{kg}^{-1}\right.\end{array}$ & $\begin{array}{c}\mathrm{Al}^{3+} \\
\left(\mathrm{cmol} \mathrm{kg}^{-1}\right)\end{array}$ & $\begin{array}{c}\mathrm{K}^{+} \\
\left(\mathrm{cmol} \mathrm{kg}^{-1}\right)\end{array}$ \\
\hline & & $0-0.02 \mathrm{~m}$ & \multicolumn{3}{|c|}{$0-0.1 \mathrm{~m}$ soil depth } & \multicolumn{3}{|c|}{$0.1-0.2 \mathrm{~m}$ soil depth } \\
\hline \multicolumn{9}{|c|}{ Mulch application 1992-1994 } \\
\hline $\begin{array}{l}\text { Stover mulch/ } \\
\text { soil deposition }\end{array}$ & $<5$ & 182 & 20.7 & 0.09 & 0.09 & 8.6 & 0.36 & 0.08 \\
\hline $\begin{array}{l}\text { Plastic mulch/ } \\
\text { soil deposition }\end{array}$ & in $10-20$ & 227 & 22.1 & 0.15 & 0.05 & 7.4 & 0.44 & 0.05 \\
\hline $\begin{array}{l}\text { Bare soil/soil } \\
\text { erosion }\end{array}$ & $45-70$ & 471 & 14.6 & 0.32 & 0.05 & 3.2 & 0.46 & 0.05 \\
\hline s.e.d. & - & 32.3 & 1.2 & 0.016 & 0.006 & 1.20 & 0.023 & 0.007 \\
\hline ANOVA & - & 0.009 & 0.035 & $\begin{array}{r}p>F \\
0.018\end{array}$ & $<0.001$ & 0.069 & 0.035 & 0.052 \\
\hline
\end{tabular}

height of the millet plants from ground level to the tip of the longest leaf was measured weekly using a ruler. Plants were cut after four weeks, and their weight was recorded, after drying to constant weight in a forced-draft oven at $60^{\circ} \mathrm{C}$. After harvest, soil from selected pots was analysed for chemical parameters using methods as described for the field trial.

The layout was regarded as a randomized $2^{7}$ factorial non-replicated experiment. As recommended for complete factorial experiments with six or more factors, fourfactor and higher-order interactions were pooled to estimate the experimental error variance (Milliken and Johnson, 1989). Data were analysed with Proc GLM in the SAS Software V. 6.12. ANOVA error probabilities less than 0.05 for treatment differences were regarded as significant.

Pot trial IV: Calcium versus $p H$ effects on millet growth when applying lime

In order to separate $\mathrm{pH}$ effects from the addition of the Ca element in the lime treatment of pot trial III, eight further pots were filled as in pot trial III for a two-factor experiment with four replicates. All the pots received the complete mixture of mineral $\mathrm{N}, \mathrm{P}, \mathrm{K}$ and micronutrients. Four of the pots received $\mathrm{Ca}$ as $\mathrm{CaCl}_{2}$ (equivalent to $\left.72 \mathrm{~kg} \mathrm{Ca} \mathrm{ha}^{-1}\right)$, the remaining four were left untreated.

\section{RESULTS}

Field trial: effects of crop residue, manure, fertilizer, and soil tillage on millet production and crop water use

Large differences were found in the soil physical and chemical properties in 1995 following three years of mulch application and erosion impact (Table 1). Erosion crusts 
Table 2. Millet dry matter production in 1995 and 1996 on plots with different mulch applications and erosion impact in the three previous years, as affected by the application of organic amendments, soil tillage, and mineral fertilizer. ICRISAT, Sadoré, Niger.

\begin{tabular}{|c|c|c|c|c|c|c|}
\hline & \multicolumn{6}{|c|}{ Millet dry matter production $\left(\mathrm{kg} \mathrm{ha}^{-1}\right)$} \\
\hline & Straw & $\begin{array}{c}\text { Grain } \\
1995\end{array}$ & Total $\dagger$ & Straw & $\begin{array}{c}\text { Grain } \\
1996\end{array}$ & Total $\dagger$ \\
\hline \multicolumn{7}{|l|}{ Mulch application 1992-1994 } \\
\hline Stover mulch/soil deposition & 1302 & 536 & 1837 & 1500 & 700 & 2584 \\
\hline Plastic mulch/soil deposition & 884 & 364 & 1248 & 1136 & 579 & 2063 \\
\hline Bare soil/soil erosion & 701 & 282 & 983 & 715 & 330 & 1236 \\
\hline \multicolumn{7}{|l|}{ Organic amendment } \\
\hline None & 375 & 143 & 518 & 601 & 310 & 1103 \\
\hline Stover mulch & 673 & 267 & 940 & 1360 & 667 & 2417 \\
\hline Manure and urine $\ddagger$ & 1839 & 771 & 2610 & 1391 & 633 & 2363 \\
\hline \multicolumn{7}{|l|}{ Soil tillage (1995 only) } \\
\hline None & 892 & 368 & 1260 & - & - & - \\
\hline Yes & 1033 & 420 & 1452 & - & - & - \\
\hline \multicolumn{7}{|l|}{ Mineral fertilizer (1996 only) } \\
\hline None & - & - & - & 637 & 312 & 1120 \\
\hline $\mathrm{N}+\mathrm{P}$ & - & - & - & 1597 & 761 & 2802 \\
\hline ANOVA $^{\S}$ & \multicolumn{6}{|c|}{$p>\mathrm{F}$} \\
\hline Mulch application 1992-1994 & 0.126 & 0.181 & 0.141 & 0.091 & 0.114 & 0.091 \\
\hline Organic amendment & $<0.001$ & $<0.001$ & $<0.001$ & $<0.001$ & $<0.001$ & $<0.001$ \\
\hline Soil tillage & 0.245 & 0.358 & 0.274 & - & - & - \\
\hline Mineral fertilizer & - & - & - & $<0.001$ & $<0.001$ & $<0.001$ \\
\hline
\end{tabular}

$\dagger$ Total above-ground dry matter, including the chaff (in 1996; chaff weight lacking in 1995).

$\ddagger$ Manure and urine were applied in 1995 only.

$\S$ Probabilities of interactions were $>0.1$ and are not shown.

were negligible on stover-mulched plots, but on bare soil more than $45 \%$ of the plot surface was crusted. Accordingly, the penetration resistance was greatest on these bare plots, and less than half on stover-mulched plots. Treatments with plastic mulch showed intermediate parameter values. P-Bray contents were relatively large in all treatments, but with a significantly higher content in both mulch treatments compared to the bare soil. Plots covered with stover mulch had $80 \%$ higher K contents than the other two treatments, and significantly less $\mathrm{Al}$. Exchangeable $\mathrm{Al}$ represented $10 \%$ of the ECEC for the mulched plots and $36 \%$ for the bare plots in the top $0.1 \mathrm{~m}$. On average, available $\mathrm{P}$ content decreased strongly with depth in all treatments, whereas exchangeable $\mathrm{Al}$ increased with depth, particularly in the mulched treatment for which it increased by a factor of four. Potassium content decreased slightly with depth in the mulched treatment only.

Millet dry matter production from stover-mulched plots was about doubled in both cropping seasons compared to bare soil without any mulch (Table 2). Due to the large variations in yield between plots, the differences were not statistically significant. There was also no significant effect of soil tillage on dry matter production in 1995. However, the single application of manure and urine in 1995, simulating the overnight kraaling 


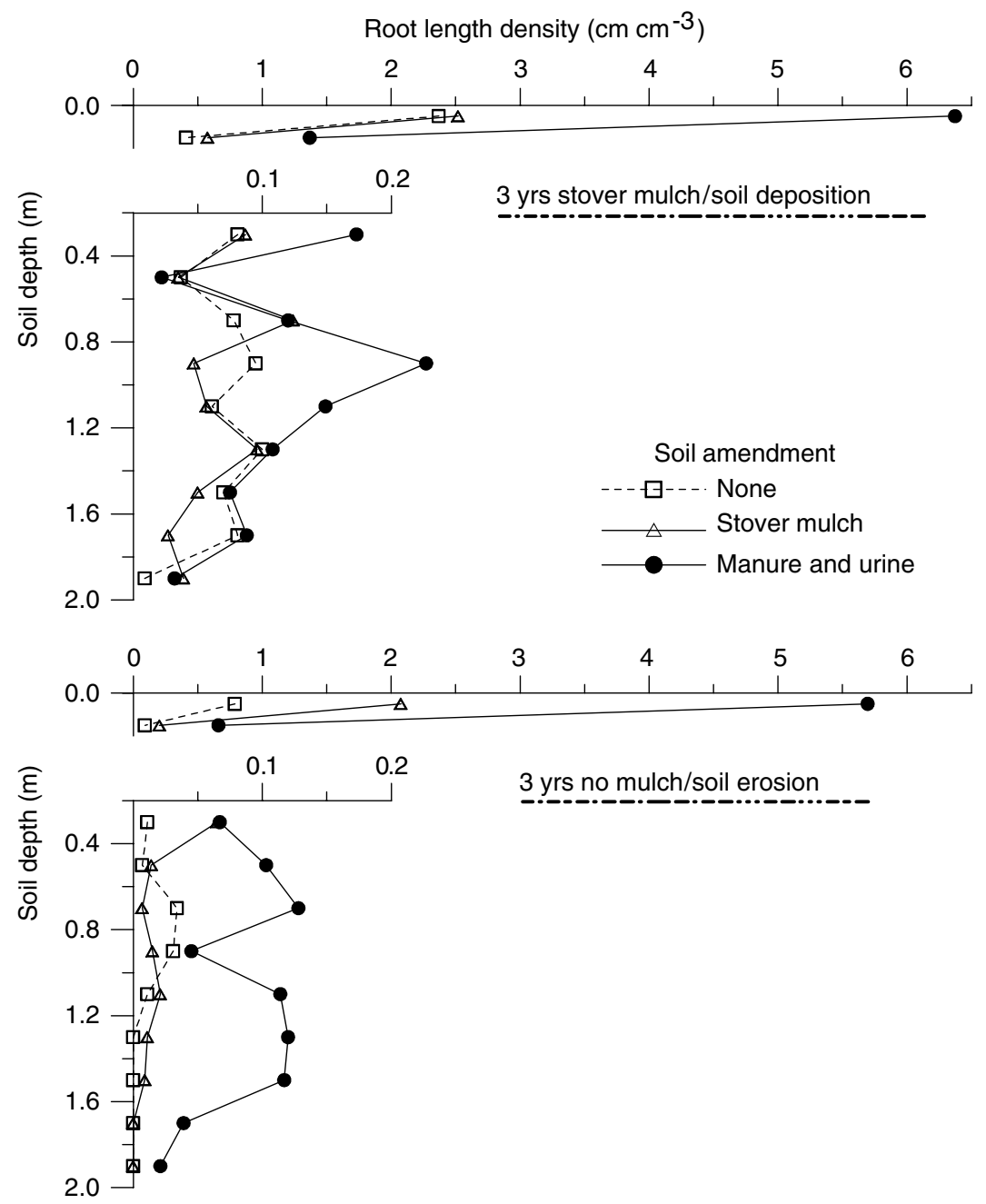

Figure 1. Millet root length density at flowering in the 1995 growing season on plots with different mulch application and erosion impact in the three previous years, as affected by organic soil amendments, ICRISAT, Sadoré, Niger.

of cattle and small ruminants, increased straw and grain yields by $173 \%$ and $188 \%$ respectively, compared to the mulched plot. Highly significant dry matter increases were still observed in 1996 compared to the bare plots but not in the mulched plots due to the residual effects of the manure and urine application. Better growth was not only observed above ground, but also for the millet roots (Figure 1). Measured root length densities were extremely low $\left(<1 \mathrm{~cm} \mathrm{~cm}^{-3}\right)$ on plots without any mulch during the previous years. Applying manure and urine increased root growth throughout the whole $2 \mathrm{~m}$ rooting zone. Mulching also resulted in the production of $250 \mathrm{~kg} \mathrm{ha}^{-1}$ weed dry matter during the 1995 growing season (data not shown), which was seven times more than on bare plots. 
Table 3. Soil water balance and water use efficiency by millet in the 1995 growing season, as affected by organic soil amendments. Cumulative rainfall during the growing period was $356 \mathrm{~mm}$. ICRISAT, Sadoré, Niger.

\begin{tabular}{lccc}
\hline & $\begin{array}{c}\text { Water drainage below } \\
1.5 \mathrm{~m} \text { soil depth }(\mathrm{mm})\end{array}$ & $\begin{array}{c}\text { Water use efficiency (WUE) } \\
\left(\mathrm{kg} \mathrm{dry} \mathrm{matter} \mathrm{ha} \mathrm{mm}^{-1}\right)\end{array}$ \\
\hline $\begin{array}{l}\text { Organic amendment } \\
\text { Stover mulch }\left(2 \mathrm{t} \mathrm{ha}^{-1}\right)\end{array}$ & 108 & 243 & 4.0 \\
$\begin{array}{c}\text { Manure }\left(10 \mathrm{t} \mathrm{ha}^{-1}\right) \text { and } \\
\text { urine }\left(1250 \mathrm{~L} \mathrm{ha}^{-1}\right)\end{array}$ & 80 & 268 & 10.00 \\
$\begin{array}{l}\text { None } \\
\text { s.e.d. }\end{array}$ & 123 & 228 & 2.3 \\
\hline ANOVA & 8.7 & 8.7 & 0.60 \\
& $<0.001$ & $p>F$ & $<0.001$ \\
\hline
\end{tabular}

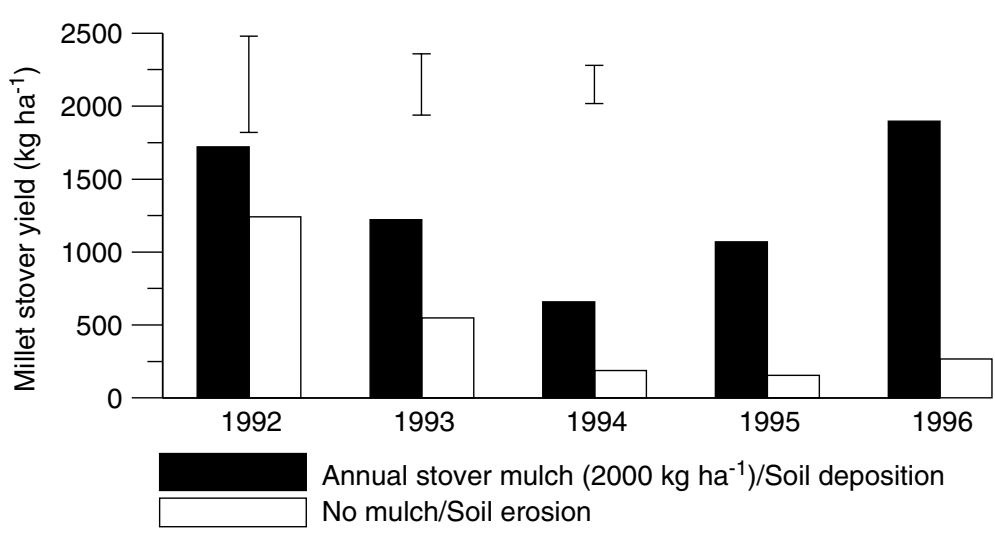

Figure 2. Millet stover dry matter production 1992-1996 on plots with and without continuous mulch application and corresponding erosion impact. Nitrogen and phosphorus fertilizer were applied annually except in 1995 . Where available vertical bars indicate one standard error of the difference, ICRISAT, Sadoré, Niger (1992-1994 data from Buerkert and Lamers, 1999).

In the 1995 growing season, with only $486 \mathrm{~mm}$ annual rainfall, $17 \%$ more water evaporated from plots with manure and urine, but these plots produced about $2092 \mathrm{~kg}$ $\mathrm{ha}^{-1}$ more total dry matter than the bare soil treatment (Table 2). As a result, water use efficiency was increased from 2.3 to $10.0 \mathrm{~kg}$ total dry matter ha $\mathrm{hm}^{-1} \mathrm{~mm}^{-1}$ upon addition of manure and urine (Table 3). The addition of $\mathrm{N}$ and $\mathrm{P}$ mineral fertilizer in 1996 increased total dry matter yields from 1120 to $2802 \mathrm{~kg} \mathrm{ha}^{-1}$ on average. There was no significant interaction between the fertilizer and the previous mulch/erosion impact treatment (Table 2).

When millet straw production data for five subsequent years were compared, no clear trend could be seen (Figure 2). Yields varied between 660 and $1900 \mathrm{~kg} \mathrm{ha}^{-1}$ when a mulch of $2 \mathrm{tha}^{-1}$ was applied each year. Except for the 1992 growing season, straw production remained low without any mulch despite fertilizer application. The lowest yields occurred in 1994, a year with $790 \mathrm{~mm}$ total rainfall. This was the highest rainfall 
Table 4. Millet seedlings emergence and root length after 72 hours in pots as affected by the field soil layer of the original material, and field mulch application and erosion impact in three previous years (pot trial I), and by millet variety (pot trial II).

\begin{tabular}{|c|c|c|}
\hline Treatment & $\begin{array}{l}\text { Emerged seedlings } \\
\% \text { pot }^{-1}\end{array}$ & $\begin{array}{c}\text { Root length } \\
\mathrm{cm}\end{array}$ \\
\hline \multicolumn{3}{|l|}{ Pot trial I } \\
\hline \multicolumn{3}{|l|}{ Soil layer in the field } \\
\hline $0-0.1 \mathrm{~m}$ & 88.2 & 8.99 \\
\hline $0.1-0.2 \mathrm{~m}$ & 77.8 & 8.96 \\
\hline $0.4-0.6 \mathrm{~m}$ & 76.2 & 10.14 \\
\hline s.e.d. & 5.3 & 0.42 \\
\hline \multicolumn{3}{|l|}{ Mulch application 1992-1994 } \\
\hline Stover mulch/soil deposition & 81.3 & 9.61 \\
\hline Plastic mulch/soil deposition & 81.1 & 9.46 \\
\hline Bare soil/soil erosion & 79.8 & 9.03 \\
\hline s.e.d. & 5.3 & 0.61 \\
\hline ANOVA & $p>F$ & \\
\hline Soil layer & 0.058 & 0.009 \\
\hline Mulching application & 0.957 & 0.476 \\
\hline Soil layer $\times$ Mulch application & 0.357 & 0.962 \\
\hline \multicolumn{3}{|l|}{ Pot trial II } \\
\hline \multicolumn{3}{|l|}{ Soil layer in the field } \\
\hline $0-0.1 \mathrm{~m}$ & 92.3 & 10.16 \\
\hline $0.4-0.6 \mathrm{~m}$ & 71.1 & 10.56 \\
\hline \multicolumn{3}{|l|}{ Millet variety } \\
\hline Improved 'ICMV 89305' & 81.3 & 9.24 \\
\hline Traditional 'Sadoré local' & 82.0 & 11.48 \\
\hline ANOVA & $p>F$ & \\
\hline Millet variety & 0.911 & $<0.001$ \\
\hline Soil layer & 0.002 & 0.272 \\
\hline Millet variety $\times$ soil layer & 0.340 & 0.052 \\
\hline
\end{tabular}

ever recorded at that site, where the long-term average annual rainfall is $545 \mathrm{~mm}$. In 1996, the total rainfall was $544 \mathrm{~mm}$.

Pot trials I and II: Al toxicity effects on millet seedling emergence and growth;

and a comparison of two millet varieties

Overall, about $80 \%$ of the millet seedlings emerged. No differences among the previous field treatments were observed (Table 4). The seedling roots developed well in all soils and reached an average length of $94 \mathrm{~mm}$ after three days. Again, the previous field treatments caused no significant differences in root length. This was also true when seedlings with root lengths $<25 \mathrm{~mm}$ were included in the analysis. Root length was increased by $13 \%$ in soil from the $0.4-0.6 \mathrm{~m}$ depth compared to the upper soil layers, but more seedlings emerged in soil from the top layer. The traditional variety Sadoré local showed a highly significant $24 \%$ increase in longer roots compared to the improved ICMV 89305 (Table 4). 
Table 5. Millet (cv. ICMV 89305) dry weight 28 days after sowing as affected by field mulch application and erosion impact in the three previous years, by mineral nutrient and nematicide application (pot trial III).

\begin{tabular}{|c|c|c|c|c|}
\hline \multicolumn{3}{|l|}{ Treatment } & $\begin{array}{l}\text { Plant dry matter } \\
\quad\left(\mathrm{g} \mathrm{pot}^{1}\right)\end{array}$ & $\begin{array}{l}\text { ANOVA } \\
(p>F)\end{array}$ \\
\hline \multicolumn{3}{|l|}{ Mulch application 1992-1994 } & & $>0.001$ \\
\hline \multicolumn{3}{|l|}{ Stover mulch/soil deposition } & 4.55 & \\
\hline \multicolumn{3}{|l|}{ Bare soil/soil erosion } & 2.52 & \\
\hline \multicolumn{3}{|l|}{ Nitrogen $(\mathrm{N})$} & & $>0.001$ \\
\hline \multicolumn{3}{|l|}{ No } & 1.48 & \\
\hline \multicolumn{3}{|l|}{ Yes } & 5.59 & \\
\hline \multicolumn{3}{|l|}{ Phosphorus (P) } & & $>0.001$ \\
\hline \multicolumn{3}{|l|}{ No } & 1.89 & \\
\hline \multicolumn{3}{|l|}{$\begin{array}{l}\text { Yes } \\
\text { Potang }(K)\end{array}$} & 5.18 & \\
\hline \multicolumn{3}{|l|}{ Potassium (K) } & & 0.137 \\
\hline \multicolumn{3}{|l|}{ No } & 3.44 & \\
\hline \multicolumn{3}{|l|}{ Yes } & 3.63 & \\
\hline \multicolumn{3}{|l|}{ Lime } & & $>0.001$ \\
\hline \multicolumn{3}{|l|}{ No } & 3.29 & \\
\hline \multirow{2}{*}{\multicolumn{3}{|c|}{$\begin{array}{l}\text { Yes } \\
\text { Micronutrients (Mn, } \mathrm{Fe}, \mathrm{Cu}, \mathrm{Zn}, \mathrm{B}, \mathrm{Mo}, \mathrm{MgO})\end{array}$}} & 3.78 & \\
\hline & & & & 0.466 \\
\hline \multicolumn{3}{|c|}{$\begin{array}{l}\text { Micronutrients (Mn, Fe, Cu, } \mathrm{Zn}, \mathrm{B}, \mathrm{Mo}, \mathrm{MgO}) \\
\text { No }\end{array}$} & 3.58 & \\
\hline \multicolumn{3}{|l|}{ Yes } & 3.49 & \\
\hline \multicolumn{3}{|l|}{ Nematicide } & & 0.985 \\
\hline \multicolumn{3}{|l|}{ No } & 3.54 & \\
\hline \multicolumn{3}{|l|}{ Yes } & 3.53 & \\
\hline \multicolumn{3}{|l|}{ Mulch application × K } & & 0.047 \\
\hline \multirow[t]{2}{*}{ Stover mulch/soil deposition } & No & & 4.58 & \\
\hline & Yes & & 4.51 & \\
\hline \multirow[t]{2}{*}{ Bare soil/soil erosion } & No & & 2.29 & \\
\hline & Yes & & & 2.75 \\
\hline \multicolumn{3}{|l|}{ Mulch application $\times \mathrm{P} \times \mathrm{N}$} & & $>0.001$ \\
\hline \multirow[t]{4}{*}{ Stover mulch/soil deposition } & No & No & 1.71 & \\
\hline & & Yes & 4.96 & \\
\hline & Yes & No & 2.85 & \\
\hline & & Yes & 8.67 & \\
\hline \multirow[t]{4}{*}{ Bare soil/Soil erosion } & No & No & 0.33 & \\
\hline & & Yes & 0.56 & \\
\hline & Yes & No & 1.04 & \\
\hline & & Yes & 8.15 & \\
\hline $\bar{P} \times \mathrm{K}$ & & & & 0.053 \\
\hline $\mathrm{N} \times \mathrm{P}$ & & & & 0.001 \\
\hline Mulch application $\times \mathrm{N}$ & & & & 0.001 \\
\hline Mulch application $\times \mathrm{P}$ & & & & 0.001 \\
\hline
\end{tabular}

Pot trial III and IV: effects of $\mathcal{N}, P, K$, lime, micronutrients and a nematicide on millet growth - and pH effect of lime vs. Ca application

The applied treatments resulted in a millet dry matter production ranging from $0.3 \mathrm{~g}$ to $8.1 \mathrm{~g} \mathrm{pot}^{-1}$ after 28 days (Table 5). Plant heights ranged between 170 and $660 \mathrm{~mm}$ after 19 days (data not shown). Phosphorus application increased overall dry matter production, but the extent depended on the respective previous field treatments 
Table 6. Soil chemical properties after millet growth in pots as affected by field mulch application and erosion impact in three previous years, and by mineral amendment (pot trial III). Field soil was taken at 0-0.2 m depth.

\begin{tabular}{|c|c|c|c|c|c|c|c|c|c|c|}
\hline Treatment & $\begin{array}{c}\mathrm{P}_{\text {Bray }} \\
\mathrm{mg} \mathrm{kg}^{-1}\end{array}$ & $\mathrm{pH}_{\mathrm{H}_{2} \mathrm{O}}$ & $\mathrm{pH}_{\mathrm{KCl}}$ & $\mathrm{H}^{+}$ & $\mathrm{Al}$ & $\mathrm{Na}$ & $\begin{array}{c}\mathrm{K} \\
\mathrm{mol} \mathrm{kg}\end{array}$ & $\mathrm{Ca}$ & $\mathrm{Mg} \mathrm{I}$ & ECEC \\
\hline \multicolumn{11}{|l|}{ Mulch application 1992-1994 } \\
\hline Stover mulch/soil deposition & 15.98 & 5.47 & 4.25 & 0.10 & 0.13 & 0.03 & 0.07 & 0.47 & 0.08 & 0.87 \\
\hline Bare soil/soil erosion & 12.84 & 5.12 & 4.09 & 0.15 & 0.29 & 0.03 & 0.06 & 0.31 & 0.05 & 0.88 \\
\hline \multicolumn{11}{|l|}{ Nitrogen $(\mathrm{N})$} \\
\hline No & 15.01 & 5.32 & 4.19 & 0.11 & 0.19 & 0.03 & 0.08 & 0.39 & 0.07 & 0.87 \\
\hline Yes & 13.82 & 5.26 & 4.15 & 0.13 & 0.22 & 0.03 & 0.05 & 0.39 & 0.06 & 0.88 \\
\hline \multicolumn{11}{|l|}{ Phosphorus (P) } \\
\hline No & 9.51 & 5.21 & 4.16 & 0.12 & 0.23 & 0.03 & 0.08 & 0.35 & 0.06 & 0.87 \\
\hline Yes & 19.31 & 5.37 & 4.18 & 0.12 & 0.19 & 0.03 & 0.06 & 0.43 & 0.06 & 0.88 \\
\hline \multicolumn{11}{|l|}{ Potassium $(\mathbf{K})$} \\
\hline No & 14.31 & 5.46 & 4.16 & 0.13 & 0.22 & 0.03 & 0.03 & 0.39 & 0.06 & 0.85 \\
\hline Yes & 14.51 & 5.12 & 4.18 & 0.12 & 0.20 & 0.03 & 0.11 & 0.39 & 0.06 & 0.90 \\
\hline \multicolumn{11}{|l|}{ Lime } \\
\hline No & 14.41 & 5.19 & 4.05 & 0.14 & 0.28 & 0.03 & 0.07 & 0.28 & 0.06 & 0.85 \\
\hline Yes & 14.42 & 5.39 & 4.29 & 0.10 & 0.14 & 0.03 & 0.06 & 0.50 & 0.06 & 0.89 \\
\hline $\mathrm{ANOVA}^{\dagger}$ & \multicolumn{10}{|c|}{$p>F$} \\
\hline Mulch application & 0.186 & 0.031 & 0.007 & 0.008 & 0.007 & $<0.001$ & 0.004 & 0.012 & 0.001 & 0.023 \\
\hline $\mathrm{N}$ & $<0.001$ & 0.146 & $<0.001$ & 0.142 & 0.004 & 0.181 & $<0.001$ & 0.084 & 0.002 & 0.880 \\
\hline $\mathrm{P}$ & $<0.001$ & 0.002 & 0.018 & 0.369 & 0.001 & 0.287 & 0.002 & $<0.001$ & 0.180 & 0.538 \\
\hline $\mathrm{K}$ & 0.325 & $<0.001$ & 0.056 & 0.343 & 0.023 & 0.967 & $<0.001$ & 0.663 & 0.466 & 0.096 \\
\hline Lime & 0.941 & $<0.001$ & $<0.001$ & $0.002<$ & 0.001 & 0.181 & 0.425 & $<0.001$ & 0.771 & 0.124 \\
\hline
\end{tabular}

$\dagger$ Significant interactions were a) $\mathrm{P} \times \mathrm{N}$ on P-Bray, $\mathrm{pH}_{\mathrm{H} 2 \mathrm{O}}, \mathrm{K}$; b) $\mathrm{K} \times \mathrm{N}$ on $\left.\mathrm{pH}_{\mathrm{H}_{2} \mathrm{O}}, \mathrm{K} ; \mathrm{c}\right) \mathrm{P} \times$ Mulch application on $\mathrm{pH}_{\mathrm{H}_{2} \mathrm{O}}$.

and the addition of N. Dry matter production on soil from bare, eroded plots tripled after $\mathrm{P}$ application without $\mathrm{N}$, and increased by a factor of 13.5 when additional $\mathrm{N}$ was applied. On previously mulched soil with sediment depositions, $\mathrm{P}$ increased dry matter production by $67 \%$ without any $\mathrm{N}$, and by $75 \%$ after the addition of $\mathrm{N}$ alone. When both $\mathrm{P}$ and $\mathrm{N}$ fertilizer were applied, dry matter yields on non-eroded and eroded soils were similar and large. Lime application significantly increased millet dry matter overall by $15 \%$. This increase through lime application can be attributed to an increased $\mathrm{pH}$ and decreased soil acidity as investigated in pot trial IV (data not shown). The effect was not due to the supply of elemental Ca.

Soil chemical properties after millet growth in pots are shown in Table 6. Phosphorus contents were large enough not to limit millet growth even without $\mathrm{P}$ application. Aluminium contents showed great variability, with the largest amounts in soils from bare eroded plots. Potassium contents did not vary much. Applying lime increased $\mathrm{pH}$ and decreased $\mathrm{Al}$ contents by $50 \%$. Soil from bare eroded plots had a lower $\mathrm{pH}$ and higher exchangeable acidity than that from mulched plots. Exchangeable $\mathrm{Al}$ comprised $0.47 \%$ and $0.27 \%$ of ECEC on bare and mulched plots respectively. ECEC was similar between treatments and acidification therefore resulted in $\mathrm{Ca}, \mathrm{Mg}$ and $\mathrm{K}$ levels lower in bare plots than on mulched plots. 
DISCUSSION

Field trial: effects of crop residue, manure, fertilizer, and soil tillage on millet production and soil water use

The large observed $\mathrm{P}$ contents in the field soil were the result of the annual addition of $\mathrm{P}$ fertilizer during the three previous cropping seasons. The amount applied was in excess of the plant's requirement at current productivity levels, which are of the order of $1-2 \mathrm{~kg} \mathrm{P} \mathrm{ha}{ }^{-1} \mathrm{a}^{-1}$. According to Bationo et al. (1991), a P-Bray-1 content of $8 \mathrm{mg} \mathrm{kg}^{-1}$ is sufficient to achieve $90 \%$ of the potential yield for millet on the sandy soils of western Niger. The smaller P-Bray values observed on the bare soil plots probably result from $\mathrm{P}$ losses in runoff water and by wind and water erosion as opposed to the mulched plots where erosion was nil. In principle, however, the measured P levels should not constitute a limiting factor for plant growth at the experimental site, irrespective of the treatments. Acidity is known to promote $\mathrm{P}$ fixation on $\mathrm{Fe} / \mathrm{Al}$ oxides, but $\mathrm{P}$ fixation is generally very low. At least in previous cropping seasons, the applied mineral $\mathrm{N}$ was sufficient and was not limiting millet growth, if not washed or blown away by top soil erosion.

The high measured water use efficiency in manured plots demonstrated that the low annual rainfall did not constitute a limiting factor for millet production when no organic amendment was applied. This result is consistent with those of Payne et al. (1992), who demonstrated that water supply cannot effectively be managed to achieve a larger millet production without addressing soil fertility constraints. Other factors, such as increased crusting and penetration resistance or low soil organic matter contents (not shown) may have contributed to restricted millet growth.

The quantities of manure and urine applied in these experiments correspond to our own findings in a survey in the Niamey region as well to the findings of Brouwer and Powell (1998). The average was $10 \mathrm{tha}^{-1}$ with a maximum values up to $30 \mathrm{tha}^{-1}$. These organic amendments provide large amounts of $\mathrm{P}$ and $\mathrm{N}$, and increase soil $\mathrm{pH}$, organic matter and nutrient availability. Powell et al. (1998) found that the positive effects of dung and urine on yield lasted up to three cropping seasons after application despite large amounts of nutrients leached to depths between 1.5 and $2 \mathrm{~m}$ (Brouwer and Powell, 1998). At least for a second season we can confirm this finding. Farmers would rather use kraaling to regain productivity on poor spots within a field explicitly than on entire fields.

\section{Pot trials I and II: Al toxicity effects on millet seedling emergency and growth; \\ and a comparison of two millet varieties}

The average root length was within the range that Ahlrichs et al. (1991) specified as normal elongation for pearl millet after three days. These authors categorized an exchangeable $\mathrm{Al}$ content of $3.3 \mathrm{cmol}_{\mathrm{c}} \mathrm{kg}^{-1}$ as moderately toxic; by comparison our soils had only $0.3 \mathrm{cmol}_{\mathrm{c}} \mathrm{kg}^{-1}$ exchangeable $\mathrm{Al}$. This is consistent with the findings of Kretzschmar et al. (1991) who showed that millet root growth is not restricted by $\mathrm{Al}$ toxicity in the acid soils from Niger. Only Davis et al. (1993) concluded that soil Al in the sandy Sahelian soils may be large enough to have toxic effects on millet roots. Our 
analyses for the $\mathrm{Al}$ content in millet plants in the field at flowering during the 1995 season (data not shown) were in the normal range as also found by Scott-Wendt et al. (1988) and Kretzschmar et al. (1991). We concluded therefore that Al had no significant adverse impact on millet emergence and root development in our conditions, and was not a cause of the small millet yields.

\section{Pot trial III and IV: effects of $\mathcal{N}, P, K$, lime, micronutrients, and a nematicide on millet growth - and pH effect of lime vs. Ca application}

Adding $\mathrm{N}$ without any $\mathrm{P}$ had no effect on millet growth on soil from previously bare eroded plots, but it more than doubled dry matter production on non-eroded soil indicating higher plant-available phosphorus reserves on previously mulched plots. Both $\mathrm{P}$ and $\mathrm{N}$ thus were essential limiting factors for plant growth in these plots. The $\mathrm{P}$ deficiency in the bare plots, despite fertilizer application in 1992-1994, may have resulted from soil erosion in the field which removed the top layer where many of the nutrients are concentrated, including surface-spread fertilizer and dust deposits rich in K, which play an important role in Sahelian nutrient balances (Herrmann, 2000). It must be pointed out that soil characteristics in the previously mulched treatment were not only influenced by soil deposition, but also by nutrient release from decomposing millet stover (Buerkert and Lamers, 1999). Given that the addition of nutrients was sufficient to bring millet dry matter production to similar levels in both treatments, this indicates that possible soil physical degradation, such as crust formation caused by erosive forces in the field, was negligible.

It remains unclear why $\mathrm{P}$ application enhanced millet growth despite the fact that measured P-Bray values were already high. Lime application probably further increased $\mathrm{P}$ availability to millet on the sandy Sahelian soils (Hafner et al., 1993). Explanations for the divergence between soil test results and actual $\mathrm{P}$ uptake by Hafner et al. (1993) relate to $\mathrm{P}$ mobility in the soil and properties of the root system. However, both causes had little relevance in our pot trial. The P-Bray method is based on $\mathrm{P}$ extraction using strong acids. This method of extraction is capable of solubilizing part of the $\mathrm{Al}$ and $\mathrm{Fe}$ compounds, thereby releasing adsorbed $\mathrm{P}$. This $\mathrm{P}$ is normally not plant available. It seems that P-Bray is therefore not suitable for determining available $\mathrm{P}$ on acidic soils for which a large fraction of the $\mathrm{P}$ is fixed onto $\mathrm{Al}$ compounds.

Potassium application resulted in significantly more dry matter production from soil on previously bare eroded plots. However, it had no effect on millet grown in previously mulched soil. This can be explained by the fact that millet stover mulch is an important source of $\mathrm{K}$ when it decomposes. Just above the significance level was the interaction of $\mathrm{P}$ and $\mathrm{K}$, indicating $10 \%$ more millet dry matter when both nutrients were simultaneously added but without any effect of $\mathrm{K}$ alone. Again, the presence of plant-available $\mathrm{P}$ was essential for the effectiveness of other nutrients. There was no indication that a lack of micronutrients limited productivity on any of the three soils. Damage by nematodes could be excluded as an explanation for the small yields observed in the field. Only third-order interactions of each N, P, and K application with 'Previous field treatment $\times$ nematicide use' were significant. Presumably, there 
was chemical interference between the nutrient formula and the pesticide rather than any nematicide effect.

Pot trial III provides indications concerning the mechanisms resulting in the low yields of millet. It appears that low yields in soil from both eroded and previously mulched plots were merely caused by nutrient depletion in the case of $\mathrm{N}$ and nutrient availability in the case of $\mathrm{P}$ on the eroded plots. In mulched plots, the annual addition of $30 \mathrm{~kg} \mathrm{Pha}{ }^{-1}$ provided ample supplies of $\mathrm{P}$, as indicated by the lack of plant response to $\mathrm{P}$ addition in the pot trial. Nitrogen fertilizer additions may not have been sufficient and $\mathrm{N}$ became limiting after $\mathrm{N}$ release from the soil organic matter pool declined. In the bare plots, both $\mathrm{N}$ and $\mathrm{P}$ deficiencies constrained crop growth. In the case of these trials, the $\mathrm{P}$ constraint on eroded plots did not result from a lack of $\mathrm{P}-$ as supported by the P-Bray levels - but from its unavailability to plants. This poor availability is hypothesized to result from $\mathrm{P}$ fixation by $\mathrm{Al}$ compounds. This process is enhanced by the acidification of the soil profile as a result of nutrient depletion and erosion. The $\mathrm{N}$ constraint found in bare soil probably results from loss of SOM by erosion.

In mulched plots, acidification is retarded as a result of the addition of nutrients, mainly $\mathrm{K}$, by decomposing residue and mineral dust deposition (Herrmann, 2000). The release of organic molecules by the decomposition process may also prevent $\mathrm{P}$ fixation by complexing exchangeable $\mathrm{Al}$ and by competing with $\mathrm{P}$ for exchange sites on $\mathrm{Al}$ and $\mathrm{Fe}$ minerals, thereby limiting $\mathrm{P}$ adsorption or even releasing adsorbed $\mathrm{P}$.

\section{CONCLUSIONS}

Addition of mineral fertilizer does not prevent land degradation on sandy Sahelian soils because acidification results in reduced $\mathrm{P}$ availability. For plots degraded by erosion, mineral $\mathrm{P}$ fertilizer addition may improve yields in the short term but $\mathrm{P}$ availability remains limited (inefficient use of $\mathrm{P}$ ). Hence, the addition of organic material is a prerequisite, by preventing acidification through the addition of exchangeable cations $(\mathrm{K})$ from dust and residue decomposition, and possibly by preventing $\mathrm{Al}$ fixation or releasing adsorbed $\mathrm{P}$ following the release of organic compounds. Manure is much more effective than straw because of the large amounts of $\mathrm{N}$ and $\mathrm{P}$ it contains. The addition of small quantities of $\mathrm{CaCO}_{3}$ may partly compensate for organic matter addition by increasing soil $\mathrm{pH}$ and reducing $\mathrm{P}$ fixation.

$\mathrm{P}$-Bray is not a good indicator of plant available $\mathrm{P}$ on degraded sandy acid soils. Ample $\mathrm{P}$ is present, as indicated by high $\mathrm{P}$-Bray values, but the $\mathrm{P}$ is not plant available, as indicated by the strong response of millet to $\mathrm{P}$ fertilizer addition in a pot trial. Despite the high percentage of the ECEC occupied by $\mathrm{Al}$ on bare soil, $\mathrm{Al}$ by itself is not a growth limiting factor, probably because the absolute amounts remain low. Neither soil physical degradation, although clearly apparent, nor water availability appear to explain low yields in the trials reported.

Acknowledgements. We are grateful to H. Thöni, University of Hohenheim, for valuable statistical advice. The constructive comments of the anonymous reviewers 
were highly appreciated. This research was funded in part by the Netherlands Directorate General for International Cooperation (DGIS).

\section{REFERENGES}

Ahlrichs, J. L., Duncan, R. R., Ejeta, G., Hill, P. R., Baligar, V. C., Wright, R. J. and Hanna, W. W. (1991). Pearl millet and sorghum tolerance to aluminium in acid soil. In Plant-soil Interactions at Low pH. Advances in Plant and Soil Sciences (Eds R. J. Wright, V. C. Baligar and R. P. Murrman). Dordrecht, The Netherlands: Kluwer Academic Publishers.

Bationo, A., Baethgen, W. E., Christianson, G. B. and Mokwunye, A. U. (1991). Comparison of five soil testing methods to establish phosphorus sufficiency levels in soil fertilized with water-soluble and sparingly soluble-P sources. Fertilizer Research 28:271-279.

Bielders, C., Michels, K. and Rajot, J.-L. (2000). On-farm evaluation of ridging and residue management practices to reduce wind erosion in Niger. Soil Science Society of America Fournal 64:1776-1785.

Bielders, C. L., Alvey, S. and Cronyn, N. (2001). Wind erosion: the perspective of grass-roots communities in the Sahel. Land Degradation and Development 12:57-70.

Bielders, C. L., Michels, K. and Bationo, A. (2002). On-farm evaluation of ridging and residue management options in a Sahelian millet-cowpea intercrop. 1. Soil quality changes. Soil Use and Management 18:216-222.

Brouwer, J. and Powell, J. M. (1998). Increasing nutrient use efficiency in West-African agriculture: the impact of micro-topography on nutrient leaching from cattle and sheep manure. Agriculture, Ecosystems and Environment 71:229-239.

Buerkert, A. and Lamers, J. P. A. (1999). Soil erosion and deposition effects on surface characteristics and pearl millet growth in the West African Sahel. Plant and Soil 215:239-253.

Davis, J. G., Hossner, L. R., and Persaud, N. (1993). Elemental toxicity effects on germination and growth of pearl millet seedlings. Fournal of Plant Nutrition 16:1957-1968.

Hafner, H., George, E., Bationo, A. and Marschner, H. (1993). Effect of crop residues on root growth and phosphorus acquisition of pearl millet in an acid sandy soil in Niger. Plant and Soil 150:117-127.

Herrmann, L. (2000). Effects of production factor gradients on agro-ecology and land use. In Adapted Farming in West Africa: Issues, Potentials and Perspectives, 353-373 (Eds F. Graef, P. Lawrence and M. von Oppen). Stuttgart, Germany: Verlag Ulrich E. Grauer.

Klaij, M. C. and Vachaud, G. (1992). Seasonal water balance of a sandy soil in Niger cropped with pearl millet, based on profile moisture measurements. Agricultural Water Management 21:313-330.

Kretzschmar, R. M., Hafner, H., Bationo, A. and Marschner, H. (1991). Long- and short-term effects of crop residues on aluminum toxicity, phosphorus availability and growth of pearl millet growth in an acid sandy soil. Plant and Soil 136:215-223.

Lal, R., Hall, G. F. and Miller, F. P. (1989). Soil degradation: I. Basic processes. Land Degradation and Rehabilitation 1:51-69.

McLean, E. O. (1982). Soil pH and lime requirement. In Methods of Soil Analysis, Part 2, Chemical and Microbiological Properties: Agronomy Monograph no. 9, 199-224 (Eds A. L. Page, R. H. Miller and D. R. Keeney). Madison, Wisconsin: American Society of Agronomy and Soil Society of America.

Michels, K., Sivakumar, M. V. K. Allison, B. E. (1995). Wind erosion control using crop residue: II. Effects on millet establishment and yields. Field Crops Research 40:111-118.

Michels, K., Lamers, J. P. A. and Buerkert, A. (1998). Effects of windbreak species and mulching on wind erosion and millet yield in the Sahel. Experimental Agriculture 34:449-464.

Milliken, G. A. and Johnson, D. E. (1989). Analysis of Messy Data. Volume 2. Nonreplicated Experiments. New York: Chapman and Hall.

Muehlig-Versen, B., Buerkert, A., Bationo, A. and Roemheld, V. (2003). Phosphorus placement on acid arenosols of the West African Sahel. Experimental Agriculture 39:307-325.

Olsen, S. R. and Sommers, L. E. (1982). Phosphorus. In: Methods of Soil Analysis, Part 2, Chemical and microbiological Properties: Agronomy Monograph no. 9, 403-430 (Eds A. L. Page, R. H. Miller and D. R. Keeney). Madison, Wisconsin: American Society of Agronomy and Soil Society of America.

Payne, W. A., Drew, M. G., Hossner, L. R., Lascano, R. J., Onken, A. B. and Wendt, C. W. (1992). Soil phosphorus availability and pearl millet water-use efficiency. Crop Science 32:1010-1015.

Powell, J. M, Ikpe, F. N., Somda, Z. C. and Fernéndez-Riveira, S. (1998). Urine effects on soil chemical properties and the impact of urine and dung on pearl millet yield. Experimental Agriculture 34:259-276. 
Rebafka, F.-P., Hebel, A., Bationo, A., Stahr, K. and Marschner, H. (1994). Short- and long-term effects of crop residues and of phosphorus fertilization on pearl millet yield on an acid sandy soil in Niger, West Africa. Field Crops Research 36:113-124.

Scott-Wendt, J., Hossner, L. R. and Chase, R. G. (1988). Variability in pearl millet (Pennisetum americanum) fields in semi-arid West Africa. Arid Soil Research and Rehabilitation 2:49-58.

Subbarao, G. V., Renard, C., Payne, W. A. and Bationo, A. (2000). Long-term effects of tillage, phosphorus fertilization and crop rotation on pearl millet-cowpea productivity in the West-African Sahel. Experimental Agriculture 36:243264.

Valentin, C. and Bresson, L. M. (1992). Soil crust morphology and forming processes in loamy and sandy soils. Geoderma 55:225-45.

West, L. T., Wilding, L. P., Landeck, J. K. and Calhoun, F. G. (1984). Soil Survey of the ICRISAT Sahelian Center, Niger, West Africa. Texas A\&M University/TropSoils, College Station, Texas. 